\title{
Characterization of the Fruit Pulp of Camu-Camu (Myrciaria dubia) of Seven Different Genotypes and Their Rankings Using Statistical Methods PCA and HCA
}

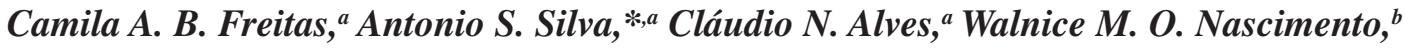 \\ Alessandra S. Lopes, ${ }^{c}$ Marcelo O. Lima ${ }^{d}$ and Regina C. S. Müller ${ }^{a}$ \\ Instituto de Ciências Exatas e Naturais, Universidade Federal do Pará, \\ Av. Augusto Corrêa, 01 Guamá, 66075-110 Belém-PA, Brazil \\ ${ }^{b}$ Laboratório de Propagação de Plantas, EMBRAPA Amazônia Oriental, \\ Av. Dr. Enéas Pinheiro, 66095-100 Belém-PA, Brazil \\ 'Instituto de Tecnologia, Universidade Federal do Pará, \\ Av. Augusto Corrêa, 01 Guamá, 66075-110 Belém-PA, Brazil \\ ${ }^{d}$ Seção de Meio Ambiente, Instituto Evandro Chagas, Rodovia BR-316, km 7, Levilandia, \\ 67000-030 Ananindeua-PA, Brazil
}

\begin{abstract}
Due to the economic potential of camu-camu, considering its high concentration of vitamin $\mathrm{C}$, the aim of this work was to evaluate the quality and genetic variability seven accessions of camucamu conserved in genebank (BAG) of Embrapa Amazônia Oriental, in the state of Pará, Amazon region, Brazil. The fruits of camucamuzeiro were analyzed for physicochemical characterization (standard methodologies) and mineral composition. The data were subjected to multivariate statistical analysis, using the techniques of cluster analysis and principal component analysis. The formation of different groups for each genotype, which shows the genetic variability and the dissimilarity of the genotypes in the species data, may be used to guide the selection of promising genotypes to enrich the programs of genetic improvement of the camucamuzeiro. Ascorbic acid showed levels above $1000 \mathrm{mg} 100 \mathrm{~g}^{-1}$, however, genotypes 4, 1 and 2 show the highest potential and the most promising nutritional capacity, but genotype 4 showed good characteristics for the moisture, acidity, carbohydrates, $\mathrm{Cu}$ and $\mathrm{Zn}$ and differs totally from others about the total soluble solids (TSS) and flavon-3-ol, features that make it the most promising genotype. It was possible to separate the seven different genotypes using multivariate analysis (hierarchical cluster analysisHCA and principal component analysis-PCA).
\end{abstract}

Keywords: camu-camu genotype, multivariate analysis, Amazon region

\section{Introduction}

Camu-camu (Myrciaria dubia) is a native fruit of the Amazon Basin belongs to the Myrtaceae family, which grows naturally at the edge of rivers and lakes of dark waters and islands, forming large forests, ${ }^{1}$ and has natural geographical distribution wide in Brazil from the Atlantic coast in the state of Pará to the region of the Tocantins river, and even the states of Mato Grosso and Rondônia, as in Preto and Uatumã rivers, ${ }^{2}$ but has greater distribution in the Peruvian Amazon.

The plant is a shrub that measures between 3 and 8 meters, ${ }^{3}$ known as camucamuzeiro, and produces fruits

*e-mail: ansansil@superig.com.br globose smooth and shiny surface, the dark red to purplish black when mature, which measure two to four inches in diameter, which are used as raw material in the preparation of juice, ice cream, jams, syrups, preservatives and natural colors for the food industry.

Cama-camu is used in the preparation of the frozen fruit pulps, as well as in cosmetics, but is due to the extremely high content of ascorbic acid (vitamin C) that camucamu has piqued the interest of many countries to present significant variation in their content, which are 0.845 to $6.1 \mathrm{~g}$ in $100 \mathrm{~g}$ the whole pulp, ${ }^{4-7}$ higher than the amount of many fruits, including acerola, whose concentration varies from 0.973 to $2.786 \mathrm{~g}$ in $100 \mathrm{~g}$ of pulp, which was considered as the richest fruit in ascorbic acid, which is an important natural antioxidant. 
The pulp of camu-camu has high acidity, low $\mathrm{pH}$ and low amounts of reducing sugars, proteins and lipids, yet has antioxidant substances characterized by high content of total polyphenols, and the rind has a high content of anthocyanins, an important antioxidant and colorant natural. ${ }^{4}$

Studies with other fruits that have antioxidants like açaí (Euterpe oleracea), bilberry (Vaccinium myrtillus), apple (Malus domestica) and orange (Citrus sinensis L.), revealed that the camu-camu has the highest values among all foods studied so far. ${ }^{8}$

The mineral content in the fruits of camu-camu can supply adequate intake of mineral elements, as they have significant concentrations of potassium, calcium, magnesium, sodium, zinc, iron, manganese, copper, aluminum, and others that are present in fruit and can participate in the diversification of food sources. ${ }^{9}$

Genetic diversity has been defined as the number of species within an ecosystem as well as the existing level of genetic variability within populations. ${ }^{10}$

The analysis of physical, physicochemical, mineral and nutritional parameters of food has been used as a useful tool to identify the quality and/or select genotypes whose interaction with the environment is more favorable and efficient, since in folk medicine and the pharmaceutical industry is increasing the use of products from fruits, for its various pharmacological properties and are of great interest from the industrial processing sector due to its taste, aroma and yield squash, characterizing them as good sources of energy, carbohydrates, vitamins, minerals and products with bioactive properties, in addition to providing flavor and variety to the diet.

Previous studies carry fruit analysis of camu-camu, but none aimed to genetic differentiation of the species through its nutritional and physicochemical parameters, for example, Justi et al. ${ }^{11}$ was performed study of physicochemical characterization of certain nutrients in frozen pulp of camu-camu stored in the laboratory; Maeda et al. ${ }^{12}$ was carried out to formulation and characterization of the camu-camu, and Rojas et al. ${ }^{13}$ was used microsatellite markers to estimate the genetic variability in population of different rivers of the Brazilian Amazon.

Because of the wide diversity of plants of camu-camu, a Germplasm Bank (BAG) of this plant was created by EMBRAPA (Brazilian Agricultural Research Corporation) Amazônia Oriental with seeds collected in different parts of the Banks of the Solimões River in the Amazon region and the present study aims to evaluate the quality of fruits from different genotypes of camu-camu, through physicochemical, chemical and mineral characterization using official tests and multivariate statistical analysis in order to identify the genetic materials with superior quality and help in the breeding program of this species.

\section{Experimental}

\section{Camu-camu samples}

Camucamuzeiro fruits of seven genotypes previously identified were selected and located in Active Bank Germosplasma (BAG) in EMBRAPA Amazônia Oriental, in the city of Belém, PA state. The fruits were harvested in the early hours of the day, between the months of January and March 2012, for each array was collected between 0.8 and $2 \mathrm{~kg}$ of fresh fruit. Each genotype was identified according to their respective headquarters and called 1,2, $3,4,5,6$ and 7. After harvest, fruits were placed in plastic bags, frozen at $20^{\circ} \mathrm{C}$, until analysis.

\section{Reagents and solutions}

All reagents were of analytical grade. Laboratory glassware was kept overnight in 10\% nitric acid solution. Before use, the glassware was rinsed with deionized water and dried in a dust-free environment. All metal solutions were prepared by diluting $1000 \mu \mathrm{g} \mathrm{mL}^{-1}$ standard solutions (Merck) with $1 \%$ hydrochloric acid solution.

\section{Physicochemical and chemical analysis}

Ash content was measured by calcination, overnight at $550^{\circ} \mathrm{C}$ in a furnace, until constant mass was achieved..$^{14}$

Moisture content was measured by the gravimetric method, ${ }^{15}$ i.e., the samples were dried at $105^{\circ} \mathrm{C}$ in an oven, until constant mass was achieved.

The $\mathrm{pH}$ was measured using a $\mathrm{pH}$ meter (Quimis-SC09, Belém-Brazil), for a $10 \%(\mathrm{~m} / \mathrm{v})$ solution prepared in distilled water. ${ }^{16}$

Total acidity (TA) was determined by the titrimetric method using a solution of $1 \%$ phenolphthalein as indicator, ${ }^{17}$ and the results were expressed in $\mathrm{g}$ of citric acid per $100 \mathrm{~mL}$ of pulp.

Total soluble solids (TSS) was measured with an Abbe refractometer (Instrutherm Instruments, São Paulo, Brazil). ${ }^{14}$ The measurements were taken at room temperature $\left(20^{\circ} \mathrm{C}\right)$.

The relationship between total soluble solids and titratable acidity (TSS/TA) was calculated as an indicator of the taste of the fruit. ${ }^{18}$

A pulp solution $20 \%(\mathrm{~m} / \mathrm{v})$ was prepared for analyzing the reducing sugar (RS) for each sample; it was withdrawn at a rate of $5.0 \mathrm{~mL}$ and transferred to a $100.0 \mathrm{~mL}$ volumetric 
flask. This solution was titrated with another solution containing $5.0 \mathrm{~mL}$ of Fehling solution $\mathrm{A}$ and $5.0 \mathrm{~mL}$ of Fehling solution B, with $20.0 \mathrm{~mL}$ water and one drop of a $1 \%$ solution of methylene blue as indicator. ${ }^{15}$

The lipid content was quantified by the Bligh-Dyer method, ${ }^{17}$ using chloroform, methanol and water to promote the extraction of the fat sample and anhydrous sodium sulfate to remove any traces of water that had remained in the lipid phase.

The protein content was determined by quantification of total nitrogen in the sample, using the Kjeldahl distiller. ${ }^{19}$ The nitrogen content was converted to protein content by multiplying the value found by the factor 6.25 .

The carbohydrate content was calculated by the difference between 100 and the sum of the percentages of water, protein, fats and ash. ${ }^{19}$

The total energy intake (in kcal $100 \mathrm{~g}^{-1}$ ) of raw fruits was estimated using the conversion values 4,4 and $9 \mathrm{kcal} \mathrm{g}^{-1}$ for protein, for carbohydrate and for lipids, respectively. ${ }^{20}$

The concentration of ascorbic acid contained in the fruit was determined by titration with potassium iodate, ${ }^{15}$ using fresh samples immediately after pulping, due to high instability of ascorbic acid.

The total polyphenols were determined by the colorimetric method of Folin-Ciocalteu. ${ }^{21} 500 \mu \mathrm{L}$ of diluted extract in which were added $250 \mu \mathrm{L}$ of Folin-Ciocalteu reagent and $1250 \mu \mathrm{L}$ of sodium carbonate, after 30 minutes the samples were read in spectrophotometer (Genesys 10uv, Belém-Brazil) at $730 \mathrm{~nm}$. The results were expressed in $\mathrm{g}$ catechin equivalents per $100 \mathrm{~g}$ pulp ( $\mathrm{g}$ Ecat $\left.100 \mathrm{~g}^{-1}\right)$. The standard curve was made using catechin.

The flavan-3-ols were determined using $p$-dimethylaminocinnamaldehyde (DMACA). ${ }^{22}$ For the preparation of the reagent were dissolved $100 \mathrm{mg}$ of DMACA in $100 \mathrm{~mL}$ of a $25 \%$ solution of $\mathrm{HCl}$ in methanol. For the analysis, $1 \mathrm{~mL}$ of the diluted extract, and $5 \mathrm{~mL}$ of DMACA solution were used. After 10 minutes the absorbance was read at $640 \mathrm{~nm}$. The results were expressed in $\mathrm{g}$ catechin equivalents per $\mathrm{g}$ of pulp $\left(\mathrm{g}\right.$ Ecat $\left.100 \mathrm{~g}^{-1}\right)$. The standard curve was made using catechin.

For determination of total anthocyanins was used $5 \mathrm{~g}$ of sample, adding about $10 \mathrm{~mL}$ of extraction solution of $95 \%$ ethanol $+1.5 \mathrm{~mol} \mathrm{~L}^{-1} \mathrm{HCl}(85: 15) .{ }^{23}$ For extraction, the material was left overnight in a refrigerator. Then it is filtered into a $100 \mathrm{~mL}$ Becker, wrapped in aluminum foil. Immediately proceeded to the reading of the absorbance at $535 \mathrm{~nm}$, with the results expressed in $\mathrm{mg} 100 \mathrm{~g} \mathrm{~g}^{-1}$ of pulp and calculated using the formula:

Anthocyanims $=\frac{\text { absorbance } \times \text { dilution factor }}{98.2}$

\section{Instrumentation}

Eight mineral elements were investigated with inductively coupled plasma optical emission spectrometry, ICP OES, (iCAP 6000-CCD series, Thermo Scientific, Madison, USA).

Instrument calibration (ICP OES) was performed using the prepared calibration solution using standard solutions of the evaluated elements ( $\mathrm{Al}, \mathrm{Ca}, \mathrm{Cu}, \mathrm{Fe}, \mathrm{K}, \mathrm{Mg}, \mathrm{Mn}, \mathrm{Na}$ and $\mathrm{Zn}$ ), Specsol, with an initial concentration of $1000 \mathrm{mg} \mathrm{L}^{-1}$.

The spectrometer was operated in the transient signal acquisition mode. A cyclonic spray chamber and concentric nebulizer were used.

The metal determinations were carried out using the manufacturer's recommended conditions for power $(1.15 \mathrm{~kW})$, plasma gas flow $\left(12 \mathrm{~L} \mathrm{~min}^{-1}\right)$, auxiliary gas flow $\left(0.5 \mathrm{~L} \mathrm{~min}^{-1}\right)$, nebulizer gas flow $\left(0.5 \mathrm{~L} \mathrm{~min}^{-1}\right)$ and also nebulizer pressure $(200 \mathrm{kPa})$. For the formation of plasma and also to transport and to assist formation of gas used was argon gas with a purity of $99.999 \%$. The emission intensity scan duration was $60 \mathrm{~s}$.

The following analytical wavelengths $(\mathrm{nm})$ were selected: Al (167.0), Ca (422.6), Cu (224.7), Fe (259.9), $\mathrm{K}$ (766.4), Mg (280.2), Mn (257.6), and $\mathrm{Na}$ (589.5).

$1 \mathrm{~g}$ of the sample was weighed in a glass digestion tube and $2.0 \mathrm{~mL}$ of $\mathrm{HNO}_{3}$ was added; this mixture was put in a digestion bloc overnight (open system). Then, $2.0 \mathrm{~mL}$ of $\mathrm{H}_{2} \mathrm{O}_{2}$ PA was added, and the mixture was heated at $150{ }^{\circ} \mathrm{C}$ for $1 \mathrm{~h}$, and at $200^{\circ} \mathrm{C}$ for $1 \mathrm{~h}$. The solution was then diluted with deionized water to $20.0 \mathrm{~mL}$. Digestion was performed in triplicate.

Blank solutions were prepared under identical conditions, but replacing the sample by deionized water, and the average signal was subtracted from the analytical signals of the pulp samples.

Limits of detection (LOD) were determined for all the mineral elements analyzed. They were determined using the formula:

LOD $=$ blank signal +3 standard deviation of the blank

Limits of Quantification (LOQ) were determined for all the mineral elements analyzed. They were determined using the formula:

$\mathrm{LOQ}=$ blank signal +10 standard deviation of the blank

The method of addition and recovery was applied using standard solutions previously prepared for each of the studied elements. The calibration curve of the concentration ranged from 1.0 at $32.0 \mathrm{~m} \mathrm{~L}^{-1}$ and the internal calibration standard 
solution has a concentration of $5 \mathrm{mg} \mathrm{L}^{-1}$ of yttrium (Y) at $1 \% \mathrm{HNO}_{3}$. The solutions were acidified with $1 \%$ (v/v) $\mathrm{HNO}_{3}$ in order to avoid precipitation of standards.

\section{Statistical analysis}

Principal component analysis (PCA) and hierarchical cluster analysis (HCA) were used for the data analysis, using the software Meet MINITAB Release 16 for Windows.

After autoscaling, the more relevant physicochemical parameters and metal content descriptors were evaluated. For this we used a correlation matrix between the calculated variables and the variance, and weighted Fisher's exact test $(p<0.05)$. This procedure determines the relative importance of each variable.

HCA was applied to the auto-scaled data, Euclidean distance with the complete linkage method was used to calculate the sample similarities, and a hierarchical agglomerative procedure was employed to establish cluster.

\section{Results and Discussion}

\section{Physicochemical parameters}

The results of the physicochemical analysis are given in Table 1, showing the average of three determinations and the standard deviation (SD).

The results of the physicochemical and chemical parameters are in agreement with values obtained by other authors that are summarized in Table 2.

The total soluble solids (TSS) indicates that the genotypes have low concentration of sugars in fruits, that may provide the greatest potential for fruit post-harvest conservation and prevents rapid deterioration and fermentation. ${ }^{24}$ Thus, genotypes 2 and 7 show better conservation characteristics than genotypes 4 and 6 . The TSS is represented prominently for organic acids. ${ }^{25,26}$

The moisture showed better results in genotypes 4 and 5 than genotypes 2 and 3 and it fits in the class of fleshy fruits and succulent as cambuci, blemish, uvaia, cherry and red guava. ${ }^{27}$

The ash contents found indicate that the genotypes 5, 6 and 7 contains higher levels of inorganic matter. Similar to those reported for other fruits such as blemish, bacuri and acerola. ${ }^{28,29}$

The $\mathrm{pH}$ values are better in genotypes 6 and 7 but lower than other fruits such as acerola, cashew, caja and blemish. ${ }^{28,30}$ Every product with $\mathrm{pH}$ below 4.50 is classified as very acidic, which gives the product a protective factor because it exerts synergistic effect on levels of water activity. ${ }^{27,31}$

The titratable acidity (TA) shows higher values in genotype 3 and also higher than in other fruits such as jaboticaba, umbu and cambuí. ${ }^{28,32,33}$

The ratio, that is the relationship between the TSS/TA, shows better results in genotypes 5 e 6 . The ratio stands out as the best practice or criterion for evaluating fruit

Table 1. Physicochemical and chemical parameters of camu-camu fruit for the seven genotypes studied ${ }^{\text {a }}$

\begin{tabular}{|c|c|c|c|c|c|c|c|}
\hline \multirow{2}{*}{ Parameter } & \multicolumn{7}{|c|}{ Genotype } \\
\hline & 1 & 2 & 3 & 4 & 5 & 6 & 7 \\
\hline $\mathrm{TSS} /{ }^{\circ} \mathrm{Brix}$ & $8.81 \pm 0.98$ & $7.58 \pm 0.93$ & $8.86 \pm 1.09$ & $11.18 \pm 2.58$ & $9.25 \pm 1.14$ & $12.32 \pm 1.01$ & $7.64 \pm 2.31$ \\
\hline Moisture / \% & $88.93 \pm 0.06$ & $92.75 \pm 0.07$ & $91.82 \pm 0.14$ & $87.42 \pm 0.08$ & $87.60 \pm 0.09$ & $89.93 \pm 0.20$ & $89.53 \pm 0.47$ \\
\hline Ash / \% & $0.31 \pm 0.03$ & $0.29 \pm 0.00$ & $0.26 \pm 0.05$ & $0.32 \pm 0.02$ & $0.34 \pm 0.02$ & $0.34 \pm 0.04$ & $0.36 \pm 0.02$ \\
\hline Protein / $\left(\mathrm{g} 100 \mathrm{~g}^{-1}\right)$ & $0.44 \pm 0.09$ & $0.17 \pm 0.01$ & $0.20 \pm 0.04$ & $0.36 \pm 0.04$ & $0.12 \pm 0.04$ & $0.37 \pm 0.04$ & $0.38 \pm 0.04$ \\
\hline $\mathrm{TA} /\left(\right.$ meq $\left.\mathrm{kg}^{-1}\right)$ & $5.15 \pm 1.13$ & $5.35 \pm 1.13$ & $4.48 \pm 0.37$ & $4.70 \pm 0.01$ & $4.70 \pm 0.00$ & $5.48 \pm 0.00$ & $4.96 \pm 1.13$ \\
\hline Ratio & 1.71 & 1.41 & 1.97 & 1.98 & 2.37 & 2.24 & 1.54 \\
\hline RS / \% & $3.77 \pm 0.29$ & $4.58 \pm 0.12$ & $4.70 \pm 0.51$ & $3.95 \pm 0.96$ & $4.48 \pm 0.00$ & $2.35 \pm 0.08$ & $2.48 \pm 0.67$ \\
\hline $\mathrm{pH}$ & $2.06 \pm 0.02$ & $2.00 \pm 0.01$ & $2.05 \pm 0.00$ & $2.06 \pm 0.01$ & $1.91 \pm 0.01$ & $1.44 \pm 0.01$ & $1.44 \pm 0.01$ \\
\hline Lipids / (g $\left.100 \mathrm{~g}^{-1}\right)$ & $0.79 \pm 0.06$ & $0.48 \pm 0.10$ & $0.24 \pm 0.01$ & $0.44 \pm 0.11$ & $0.28 \pm 0.05$ & $0.40 \pm 0.04$ & $0.29 \pm 0.06$ \\
\hline Flavan-3-ol / (mg of Cat $\left.\mathrm{g}^{-1}\right)$ & $111.76 \pm 6.00$ & $61.82 \pm 0.38$ & $64.43 \pm 1.43$ & $98.38 \pm 6.46$ & $118.94 \pm 1.38$ & $211.64 \pm 6.92$ & $69.65 \pm 3.69$ \\
\hline Calorie / kcal & 46.29 & 30.24 & 32.68 & 50.64 & 50.64 & 41.42 & 41.69 \\
\hline Vitamin C / $\left(\mathrm{mg} \mathrm{g}^{-1}\right)$ & $2289.56 \pm 0.00$ & $2348.26 \pm 134.51$ & $2172.14 \pm 183.31$ & $2935.33 \pm 134.51$ & $2905.98 \pm 152.52$ & $1819.90 \pm 50.84$ & $1790.55 \pm 134.51$ \\
\hline $\mathrm{PC} /\left(\mathrm{mg}\right.$ of Cat g $\left.\mathrm{g}^{-1}\right)$ & $1649.96 \pm 109.64$ & $2004.5 \pm 92.33$ & $1919.26 \pm 17.31$ & $1237.86 \pm 11.54$ & $1890.70 \pm 46.16$ & $1348.03 \pm 317.37$ & $1698.62 \pm 11.54$ \\
\hline Carbohydrate / \% & 9.67 & 6.37 & 7.59 & 11.68 & 11.50 & 8.99 & 9.51 \\
\hline Anthocyanis / $\left(\mathrm{mg} \mathrm{g}^{-1}\right)$ & $0.98 \pm 0.07$ & $1.11 \pm 0.38$ & $1.06 \pm 0.13$ & $0.99 \pm 0.26$ & $0.93 \pm 0.24$ & $1.16 \pm 0.13$ & $0.84 \pm 0.04$ \\
\hline
\end{tabular}

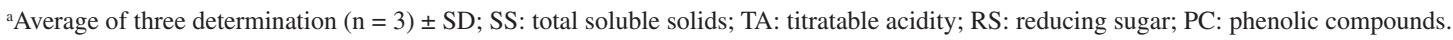


Table 2. Comparison between data of literature and the results of this work

\begin{tabular}{|c|c|c|}
\hline Parameter & This work & Literature \\
\hline TSS $/{ }^{\circ}$ Brix & 9.39 & $6.2^{34}$ and $7.31^{25}$ \\
\hline Ash / \% & 1.80 & between $2.44^{35}$ and $2.64^{12,36}$ \\
\hline $\mathrm{TA} / \%$ & 4.97 & between $2.30^{36}$ and $2.86^{35}$ \\
\hline Ratio & 1.88 & $1.82^{34}$ and $2.23^{35}$ \\
\hline $\mathrm{RS} / \%$ & 4.58 at 2.48 & $2.05,,^{25} 2.96,{ }^{12} 3.25^{36}$ and $4.4^{32}$ \\
\hline Protein / $\left(\mathrm{g} 100 \mathrm{~g}^{-1}\right)$ & 0.44 at 0.12 & $0.29,{ }^{12} 0.4,{ }^{35}$ and $0.5^{2}$ \\
\hline Lipids / (g $\left.100 \mathrm{~g}^{-1}\right)$ & 0.79 and 0.24 & $0.05^{12,32}$ \\
\hline Carbohydrate / \% & 11.68 at 6.37 & 6.6 and $10.84^{37}$ \\
\hline Calorie / kcal & 50.64 and 30.24 & $52.76^{37}$ and $7.4^{38}$ \\
\hline Vitamin $\mathrm{C} /\left(\mathrm{mg} \mathrm{g}^{-1}\right)$ & 2260.57 & 0.934 a $6.112^{4,5,7,38}$ \\
\hline $\mathrm{PC} /\left(\mathrm{mg}\right.$ of catequine $\left.100 \mathrm{~g}^{-1}\right)$ & 2625.4 and 1237.86 & $1797,{ }^{39} 1320,{ }^{30}$ and $1417.80^{39}$ \\
\hline Flavan-3-ol / (mg $\left.100 \mathrm{~g}^{-1}\right)$ & 211.64 and 61.82 & 55.1 and $56.7^{30}$ \\
\hline Anthocyanis / (mg $\left.100 \mathrm{~g}^{-1}\right)$ & 1.16 and 0.46 & 0.85 and $0.14^{12}$ \\
\hline
\end{tabular}

TSS: total soluble solids; TA: titratable acidity; RS: reducing sugar; PC: phenolic compounds.

flavor, being more efficient than considering only levels of sugars and/or acidity, quantified in isolation. ${ }^{40,41}$ For the camu-camu the values were lower than those of caja, guava and umbu. ${ }^{32}$

The values for the total reducing sugars showing the genotypes 2 and 3 are the highest among the analyzed, however the total sugar content in ripe camu-camu (Myrciariadubia) is very low compared to most other fruits as the blemish and the grape. ${ }^{28,36}$

The protein content of $100 \mathrm{~g}$ of frozen pulp are higher for the genotype 1 , however, the results showing that the pulp of camu-camu contains small amounts of proteins when related to other fruits.

The genotype 3 has the lowest content of lipids of $100 \mathrm{~g}$ of frozen pulp and due to the very low level that is less than $1 \%$ of the chemical composition of this fruit the lipids were not quantified in some studies.

The carbohydrate content is higher in genotypes 4 and 5 and lower in genotype 2, a factor that correlates to the TSS levels.

The vitamin C content is higher in genotype 4, differing significantly from the other genotypes, but in all others this values is similarly high and much higher than those found for other fruits like caja, cashew, acerola, pineapple, grape and guava. ${ }^{36}$ Thus the fruit camu-camu provides important contribution in enrichment in the diet, because in just $100 \mathrm{~g}$ pulp has about thirty times the Recommended Daily Intake by law for healthy adults of vitamin C per day, which is 75-90 mg for adults and 35-45 mg for children. ${ }^{31,42}$

The pulp of camu-camu (Myrciaria dubia) showed levels of phenolic compounds higher in genotype 2 but is lower than blemish, jambolan and guava-red, ${ }^{43}$ the same occurs with the fruits of other families like açaí, acerola and black-netting. ${ }^{44}$

The camu-camu (Myrciaria dubia) pulp showed levels of flavan-3-ols higher in genotype 6, being the most representative phenolic compound in the evaluation of antioxidant capacity as well in pulp tucumã, carambola and soursop. ${ }^{45}$

The pulp of camu-camu (Myrciaria dubia) showed higher level of anthocyanins in genotype 6 , but lower than other fruits of the same family (Myrtaceae) were found in fruits from Florida State anthocyanins levels equal to

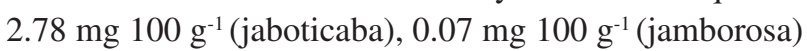
and $6.33 \mathrm{mg} 100 \mathrm{~g}^{-1}$ (jamelão). ${ }^{46}$

\section{Mineral contents}

The obtained recovery (\%) values were: $\mathrm{Al}$ (98.67), $\mathrm{Ca}$ (99.95), Cu (97.27), Fe (94.70), K (102.99), Mg (98.67), $\mathrm{Mn}$ (98.45), and $\mathrm{Na}$ (96.36).

The limits of detection $\left(\mathrm{mg} \mathrm{kg}^{-1}\right)$ obtained were: $\mathrm{Al}$ (0.00200), $\mathrm{Ca}(0.00016), \mathrm{Cu}(0.00070), \mathrm{Fe}(0.00061)$, $\mathrm{K}$ (0.00042), Mg (0.00002), Mn (0.00012), Na (0.00018) and $\mathrm{Zn}(0.00009)$.

The limits of quantification $\left(\mathrm{mg} \mathrm{kg}^{-1}\right)$ obtained were: $\mathrm{Al}$ (0.0130), Ca (0.0012), Cu (0.0025), Fe (0.0021), $\mathrm{K}(0.0014), \mathrm{Mg}(0.0020), \mathrm{Mn}(0.0043), \mathrm{Na}(0.0063)$ and $\mathrm{Zn}(0.0091)$.

The results of nine mineral determinations are given in Table 3, showing the average of three determinations and the standard deviation (SD) related to the 3 measurements of the complete analysis (digestion and measurement). 
Table 3. Mineral contents of camu-camu fruit for the seven genotypes studied ${ }^{a}$

\begin{tabular}{|c|c|c|c|c|c|c|c|}
\hline \multirow{2}{*}{ Mineral } & \multicolumn{7}{|c|}{ Genotype } \\
\hline & 1 & 2 & 3 & 4 & 5 & 6 & 7 \\
\hline $\mathrm{Al} /\left(\mathrm{mg} \mathrm{kg}^{-1}\right)$ & $4.33 \pm 0.09$ & $16.00 \pm 2.59$ & $11.62 \pm 1.83$ & $21.53 \pm 0.22$ & $16.67 \pm 2.24$ & $18.16 \pm 1.42$ & $45.95 \pm 12.85$ \\
\hline $\mathrm{Ca} /\left(\mathrm{mg} \mathrm{kg}^{-1}\right)$ & $98.71 \pm 2.48$ & $163.80 \pm 18.70$ & $110.50 \pm 9.66$ & $82.85 \pm 8.63$ & $145.90 \pm 15.90$ & $143.60 \pm 14.45$ & $107.01 \pm 12.46$ \\
\hline $\mathrm{Cu} /\left(\mathrm{mg} \mathrm{kg}^{-1}\right)$ & $0.55 \pm 0.14$ & $0.50 \pm 0.01$ & $0.93 \pm 0.08$ & $3.35 \pm 0.44$ & $1.61 \pm 0.32$ & $2.58 \pm 1.82$ & $0.27 \pm 0.06$ \\
\hline $\mathrm{Fe} /\left(\mathrm{mg} \mathrm{kg}^{-1}\right)$ & $4.12 \pm 0.81$ & $39.40 \pm 1.36$ & $29.15 \pm 4.68$ & $38.40 \pm 3.23$ & $29.27 \pm 3.33$ & $33.29 \pm 4.57$ & $4.82 \pm 0.50$ \\
\hline $\mathrm{K} /\left(\mathrm{mg} \mathrm{kg}^{-1}\right)$ & $1076.00 \pm 7.81$ & $848.23 \pm 69.40$ & $760.20 \pm 56.13$ & $883.46 \pm 26.83$ & $677.43 \pm 23.89$ & $928.26 \pm 93.21$ & $748.83 \pm 83.14$ \\
\hline $\mathrm{Mg} /\left(\mathrm{mg} \mathrm{kg}^{-1}\right)$ & $54.42 \pm 2.04$ & $49.01 \pm 8.75$ & $35.49 \pm 2.71$ & $52.86 \pm 6.79$ & $53.30 \pm 7.75$ & $44.79 \pm 6.91$ & $40.56 \pm 4.13$ \\
\hline $\mathrm{Mn} /\left(\mathrm{mg} \mathrm{kg}^{-1}\right)$ & $1.24 \pm 0.02$ & $4.83 \pm 0.60$ & $1.63 \pm 0.17$ & $1.56 \pm 0.10$ & $2.12 \pm 0.15$ & $2.00 \pm 0.21$ & $1.57 \pm 0.15$ \\
\hline $\mathrm{Na} /\left(\mathrm{mg} \mathrm{kg}^{-1}\right)$ & $63.42 \pm 1.50$ & $52.79 \pm 0.59$ & $54.77 \pm 2.44$ & $62.26 \pm 7.63$ & $48.88 \pm 2.39$ & $52.84 \pm 10.30$ & $78.74 \pm 14.48$ \\
\hline $\mathrm{Zn} /\left(\mathrm{mg} \mathrm{kg}^{-1}\right)$ & $3.42 \pm 0.54$ & $16.38 \pm 0.24$ & $16.98 \pm 1.88$ & $18.87 \pm 1.31$ & $17.19 \pm 0.84$ & $18.65 \pm 1.64$ & $3.76 \pm 0.31$ \\
\hline
\end{tabular}

${ }^{a}$ Average of three determinations \pm standard deviation.

The aluminum content in the pulp appeared considerably high due to the soil in which fruits were grown. The World Health Organization recommends limiting the intake of aluminum to the amount of $1 \mathrm{mg}$ per kilogram of body weight per day. So, as the levels of aluminum are high, they are still at safe levels for human consumption.

Calcium was the second most abundant mineral in the fruit pulp. Similar results are found in the literature, ${ }^{9,39}$ and higher concentrations found for the fruit of the same family as jambo (Syzygium jambos) and araçá-boi (Eugenia stipitata). ${ }^{4}$ The concentration of calcium in the fruit is much lower when compared with dairy products, but compared to other conventional fruits is what is closest to everyday values recommended by the Ministry of Health, which are for adults: $800 \mathrm{mg}$; infants: $400-600 \mathrm{mg}$; pregnant: 1,200 mg and children: 800-1,200 mg.

Copper was the studied mineral of lower concentration in the fruit pulp, which is consistent with values reported in the literature, ${ }^{39}$ such higher concentrations to those found in acerola (Malpighia emarginata), ${ }^{9}$ but are lower than those set by the World Health Organization as safe limit of your daily intake.

The iron contents are similar to those found in the literature, ${ }^{9,39}$ being higher than those found for the jambo (Syzygium jambos) and lower for araçá-boi (Eugenia stipitata). ${ }^{5}$ Are also higher concentrations to daily values recommended by the Ministry of Health, which are for adults: men, women: $10 \mathrm{mg}$ and $15 \mathrm{mg}$, respectively; pregnancy and lactation: 30 and $15 \mathrm{mg}$, respectively; infants: $6-10 \mathrm{mg}$ and children: $10-12 \mathrm{mg}$.

The potassium content found in this study is in agreement with literature results, ${ }^{9,39}$ but are lower than the concentrations found for jambo (Syzygium jambos) and superior to the araçá-boi (Eugenia stipitata), ${ }^{5}$ approaching the daily amounts recommended by the Ministry of Health, which are for adults: $2000 \mathrm{mg}$; infants: $500-670 \mathrm{mg}$, and children: 1000-2000 mg.

The magnesium content found in the pulps was lower than those in the literature for camu-camu, ${ }^{39}$ and found to acerola (Malpighia emarginata). ${ }^{9}$ The values are close to the daily amounts recommended by the Ministry of Health, which are for adults: $280-350 \mathrm{mg}$; infants: $40-60 \mathrm{mg}$; pregnant: $290-355 \mathrm{mg}$ and children: $80-170 \mathrm{mg}$.

The manganese content in the pulp found in camucamu (Myrciaria dubia) pulp is lower than those reported in literature ${ }^{39}$ and the values found for fruit in the same family as rose jambo (Syzygium jambos) and araçá-boi (Eugenia stipitata) ${ }^{5}$ and the values found for acerola (Malpighia emarginata). ${ }^{9}$ These values are higher than the daily recommended values by the Health Ministry, which are for adults: 2-5 $\mu$ g; infants: 0.3 to $1.0 \mu \mathrm{g}$ and children: $1-5 \mu \mathrm{g}$, which suggests that camu-camu is an excellent source of this mineral for human nutrition.

Sodium concentrations found in the pulp of camu-camu (Myrciaria dubia) are lower than those reported in previous studies ${ }^{39}$ and are less than the concentrations found for jambo (Syzygium jambos) and superior to araçá-boi (Eugenia stipitata), ${ }^{5}$ and similar to those found in acerola (Malpighia emarginata). ${ }^{9}$ Concentrations are less than the daily recommended values by the Health Ministry, which are for adults: $500 \mathrm{mg}$; infants: $120-200 \mathrm{mg}$ and children: 225-500 mg.

The zinc content in the pulp of camu-camu (Myrciaria dubia) is higher than those found in the literature, ${ }^{9,39}$ upper found for fruits of the same family as jambo (Syzygium jambos) and araçá-boi (Eugenia stipitata). ${ }^{5}$ These results are close to daily values recommended by the Ministry of Health, which are for adults: $12-15 \mathrm{mg}$; infants: $5 \mathrm{mg}$ and children: $10-15 \mathrm{mg}$. 


\section{Multivariate analysis}

PCA and HCA methods showed a separation of the seven groups according to genotype of camu-camu (Myrciaria dubia) was obtained for only one metal contents $(\mathrm{Mn})$ and only three physicochemical parameters $(\mathrm{pH}$, flavan-3-ols and phenolic compounds).

The results obtained by HCA method are shown as a dendrogram in Figure 1. In this graphic, vertical lines represent camu-camu (Myrciaria dubia) pulp samples and horizontal lines represent similarities (\%) between samples in terms of the Euclidian distances that originate from the cluster analysis between samples and a group of samples, and between groups of samples.

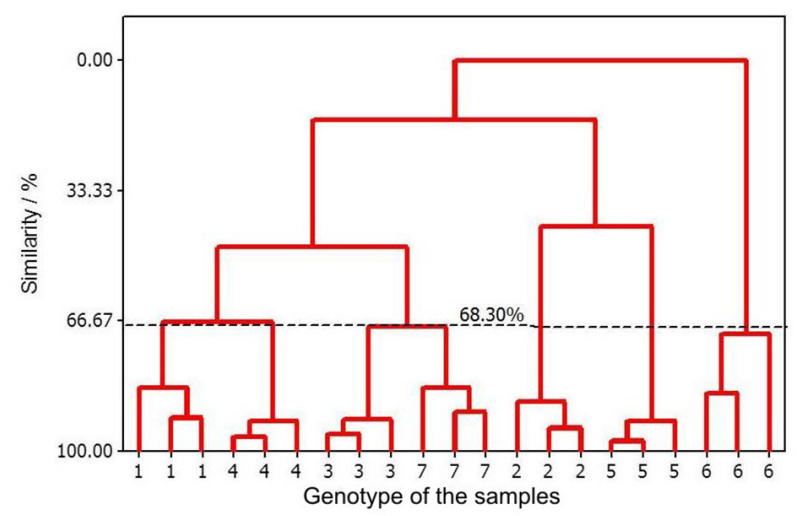

Figure 1. Dendrogram of cluster analysis of physicochemical parameters and mineral contents.

Seven clusters were found at a similarity level of $68.30 \%$, and each of which is composed of groups formed by samples of the same genotype camu-camu (Myrciaria dubia) studied, which enables excellent separation of the genotypes based on the five parameters used for the hierarchical cluster analysis (HCA).

PCA was performed on the autoscaled and standardized data. From the loadings of the original variables in the first two principal components considered, it was established that: principal component one (PC1) represents $44.20 \%$ of the total variance, and is given by the expression $\mathrm{PC} 1=0.107(\mathrm{pH})+0.593$ (phenolic compound) - 0.575(flavan-3-ols) $+0.554(\mathrm{Mn})$; while principal component two (PC2) explains up to $27.50 \%$ of the total variance and is given by the expression $\mathrm{PC} 2=-0.821(\mathrm{pH})+$ 0.226 (phenolic compound) +0.403 (flavan-3-ols $)+$ $0.335(\mathrm{Mn})$. The first two principal components account for $87.70 \%$ of the total variance and were considered to be sufficient for the data.

Figure 2 shows that the Mn contents, $\mathrm{pH}$ and flavan-3-ols are the most important variables explaining the separation between the seven genotypes of camu-camu in PC2, and that the values of flavan-3-ols and Mn levels are the most important variables explaining the separation between the seven genotypes of camu-camu (Myrciaria dubia) in PC1.

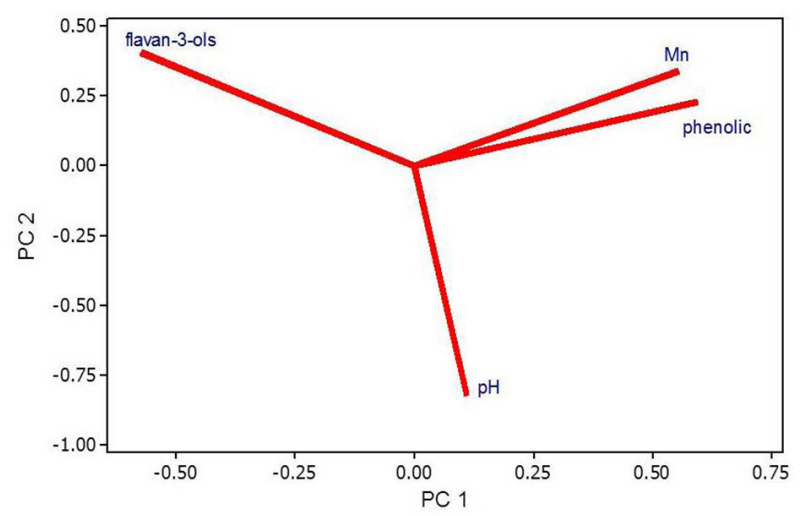

Figure 2. Graphic of the loading for the two principal components.

On examining the score plot of the objects in the space defined by the two principal components (Figure 3), it was found the seven pulps of camu-camu (Myrciaria dubia) groups could be separated according to different genotypes studied. All samples were correctly grouped.

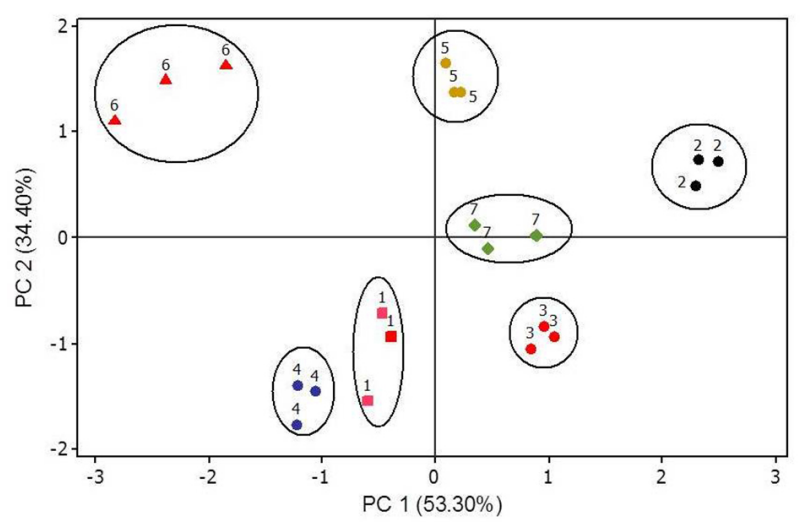

Figure 3. Principal component score plot of the separation of samples of camu-camu (Myrciaria dubia) pulps by genotypic origin.

Based on the classification obtained using HCA and PCA, we can say that flavan-3-ols, phenolic compounds, $\mathrm{pH}$, and $\mathrm{Mn}$ contents are responsible for the separation between the seven genotypes of camu-camu (Myrciaria dubia) studied.

\section{Conclusions}

The physicochemical characterization of the fruit allows the identification of genetic variability among the progenies of Myrciaria dubia established in BAG-camu-camu, principally related to the high content of vitamin $\mathrm{C}$ which makes this fruit an interesting model for the study and 
characterization under various aspects, both in molecular approaches to identification and isolation of genes, such as for using these as nutraceutical food, in cosmetics and as a justification for encouraging the production and consumption of this fruit by population.

The results obtained for the physico-chemical parameters and minerals are indicative of significant genetic variability, which is crucial for the establishment and maintenance of the breeding program of the camucamuzeiro.

The vitamin C parameter stands out as decisive for the election of genotype of higher quality among the studied when correlated with other parameters set difference and relative importance among genotypes. Genotypes 4, 1 and 3 show the highest potential, respectively, as being the most promising nutritional capacity and the enrichment diet.

Regarding the content of ascorbic acid, all genotypes

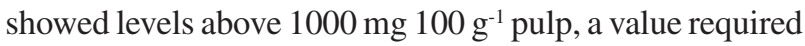
for export. However, genotypes 4, 1 and 2 show the highest potential, respectively, the most promising being the nutritional capacity and the enrichment diet. Genotype 4 also showed good characteristics for the moisture, acidity, carbohydrates, $\mathrm{Cu}$ and $\mathrm{Zn}$ and differs totally from others about the TSS and flavon-3-ol, features that make it the most promising genotype, among seven analyzed when correlated to its total mineral content and total bioactive compounds. Genotype 1 has a high nutritional value in relation to protein, lipids and total mineral because it contains high levels of potassium and magnesium. Genotype 2 stands out for presenting best feature of TSS, reducing sugars, calories, total polyphenols, carbohydrates, $\mathrm{Ca}, \mathrm{Fe}$ and $\mathrm{Mn}$. Genotype 5 shows good characteristics for reducing sugars, titratable acidity, ratio, flavon-3-ol and total bioactive compounds, but had the lowest levels of total minerals.

The results of physico-chemical parameters and the analyzed metal content showed that the seven genotypes of camu-camu have good quality and are suitable for human consumption.

HCA and PCA methods, using only three physicochemical parameters $(\mathrm{pH}$, phenolic compounds and flavan-3-ols) and only two mineral contents (Mn and $\mathrm{Zn}$ ), showed that pulps of camu-camu (Myrciaria dubia) samples from seven different genotypes could be aligned into seven groups. Then, these methods can be employed to distinguish the seven genotypes of camu-camu.

\section{Acknowledgments}

We are grateful for the support of Instituto Evandro Chagas. The authors thank all who cooperated directly or indirectly in this study.

\section{References}

1. McVaugh, R.; Mem. N. Y. Bot. Gard. 1969, 18, 55.

2. Villachica, L. H.; El Cultivo de Camu-Camu (Myrciaria dubia H. B. K. Mc Vaugh) en la Amazonia Peruana; Tratado de Cooperacion Amazonica: Lima, Peru, 1996, p. 95.

3. Alves, R. E.; Filgueiras, H. A. C.; Moura, C. F. H.; Caracterização de Frutas Nativas da América Latina; Funep: Jaboticabal, 2000.

4. Andrade, J. S.; Galeazzi, M. A. M.; Aragão, C. G.; Chavez Flores, W. B.; Rev. Bras. Frutic. 1991, 13, 307.

5. Yuyama, K.; Aguiar, J. P. L.; Yuyama, L. K. O.; Acta Amaz. 2002, 32, 169.

6. Smiderle, O. J.; Sousa, R. C. P.; Agro@mbiente On-line 2008, 2, 2.

7. Cohen, K. O.; Monte, D. C.; Paes, N. S.; Ribeiro, S. I.; Determinação de Compostos Antioxidantes nos Frutos de Cати-Camu, Boletim de Pesquisa e Desenvolvimento, 266; Embrapa Cerrados: Planaltina, 2010.

8. Rodrigues, R. B.; Papagiannopoulos, M.; Maia, J. G. S.; Ernahrung Neu-Isenburg 2006, 30, 357.

9. Yuyama, L. K. O.; Aguiar, J. P. L.; Yuyama, K.; Lopes, T. M.; Favaro, D. I. T.; Bergl, P. C. P.; Vasconcelos, M. B. A.; Acta Amaz. 2003, 33, 549.

10. Nei, M.; Proc. Natl. Acad. Sci. USA 1973, 70, 3321.

11. Justi, K. C.; Visentainer, J. V.; Evelazio de Souza, N. E.; Matsushita, M.; Arch. Latinoam. Nutr. 2000, 50, 405.

12. Maeda, R. N.; Pantoja, L.; Yuyama, L. K. O.; Chaar, J. M.; Ciênc. Tecnol. Aliment. 2006, 26, 70.

13. Rojas, S.; Clement Ch., Y. K.; Nagao, E. O.; Revista Corpoica - Ciencia y Tecnología Agropecuaria 2011, 12, 51.

14. Brasil, Ministério da Agricultura e do Abastecimento; Instrução Normativa No. 1, de 7 de janeiro de 2000, Aprova o Regulamento Técnico Geral para Fixação dos Padrões de Identidade e Qualidade para Polpa de Fruta. Available at http://extranet. agricultura.gov.br/sislegis-consulta/consultarLegislacao. do?operacao=visualizar\&id=7777, accessed in February 2016.

15. Instituto Adolfo Lutz; Normas Analíticas, Métodos Químicos e Físicos para Análises de Alimentos, $3^{\mathrm{a}}$ ed.; IAL: São Paulo, 1985.

16. Lanara; Métodos Analíticos para Controle de Produtos de Origem Animal e Ingredientes II Métodos Físicos e Químicos, 1981.

17. Association of Official Analytical Chemists (AOAC): Official Methods of Analysis, 16 $6^{\text {th }}$ ed.; Washington, DC, 1997.

18. Baldwin, E. A.; Flavor USDA/ARS, Citrus and Subtropical Products Laboratory; Winter Haven: Florida, EUA. Available at: http://www.ars.usda.gov/pandp/people/people. htm?personid=263, accessed on February 21, 2016.

19. Association of Official Analytical Chemists (AOAC): Official Methods of Analysis, 18 th ed.; Washington, DC, 1997. 
20. Merril, A. L.; Watt, B. K.; Energy Value of Foods: Basis and Derivation; United States Department of Agriculture: Washington, USA, 1973.

21. Singleton, V. L.; Rossi, J. A.; Am. J. Enol. Vitic. 1965, 16, 144.

22. Delcour, J. A.; Janssens de Varebeke, D.; J. Inst. Brew., Suppl. 1985, $91,37$.

23. Francis, F. J. In Anthocyanins as Food Colors; Markakis, P., ed.; Academic Press: New York, USA, 1982, 181.

24. Brunini, M. A.; Oliveira, A. L.; Salandini, C. A. R.; Bazzo, F. R.; Ciênc. Tecnol. Aliment. 2004, 24, 378.

25. Maeda, R. N.; Andrade, J. S.; Acta Amaz. 2003, 33, 489.

26. Silva, T. V.; Resende, E. D.; Viana, A. P.; Rosa, R. C. C.; Pereira, S. M. F.; Carlos, L. A.; Vitorazi, L.; Rev. Bras. Frutic. 2005, 27, 472.

27. Vallilo, M. I.; Garbelotti, M. L.; de Oliveira, E.; Lamardo, L. C. A.; Rev. Bras. Fruticultura 2005, 27, 241.

28. Sato, A. C. K.; Cunha, R. L.; J. Food Eng. 2009, 91, 566.

29. Gadelha, A. J. F.; Rocha, C. O.; Vieira, F. F.; Ribeiro, G. N.; Revista Caatinga 2009, 22, 115.

30. Chirinos, R.; Galarza, J.; Betalleluz-Pallardel, I.; Pedreschi, R.; Campos, D.; Food Chem. 2010, 120, 1019.

31. Azeredo, H. M. C.; Brito, E. S. In Fundamentos de Estabilidade de Alimentos; Azeredo, H. M. C., ed.; Embrapa Agroindústria Tropical: Fortaleza, Brasil, 2004.

32. Machado, A. Q.; Alvarenga, M. A. R.; Florentino, C. E. T.; Hortic. Bras. 2007, 25, 149.

33. Pinheiro, L. R.; Almeida, C. S.; Silva, A. V. C.; Sci. Plena 2011, 7, 1 .

34. Maeda, R. N.; Pantoja, L.; Yuyama, L. K. O.; Chaar, J. M.; Ciênc. Tecnol. Aliment. 2007, 27, 313.
35. Akter, M. S.; Oh, S.; Eun, J. B.; Ahmed, M.; Food Res. Int. 2011, 44, 1728.

36. Dantas, R. L.; Rocha, A. P. T.; Araújo, A. S.; Rodrigues, M. S. A.; Maranhão, T. K. L.; Revista Verde 2010, 5, 61.

37. Nascimento, O. V.; Boleti, A. P. A.; Yuyama, L. K. O.; Lima, E. S.; An. Acad. Bras. Cienc. 2013, 85, 355.

38. Schwertz, M. C.; Maia, J. R. P.; de Sousa, R. F. S.; Aguiar, J. P. L.; Yuyama, L. K. O.; Lima, E. S.; Rev. Nutr. 2012, 25, 35.

39. Cozzolino, S. M. F.; Biodisponibilidade de Nutrientes; Manole: Barueri, 2005.

40. Pinto, W. S.; Dantas, A. C. V. L.; Fonseca, A. A. O.; Ledo, C. A. S. L.; de Jesus, S. C.; Calafange, P. L. P.; Andrade, E. M.; Pesq. Agropec. Bras. 2003, 38, 1059.

41. Chitarra, A. B.; Chitarra, M. I. F.; Pós-Colheita de Frutos e Hortaliças: Fisiologia e Manuseio, Vol. 1, 2ª ed.; UFLA: Lavras, 2005.

42. Franceschini, S. C. C.; Priore, S. E.; Euclydes, M. P.; In Guia de Nutrição: Nutrição Clínica no Adulto; Cuppari, L., ed.; Manole Ltda.: Barueri, 2002.

43. Visentainer, J. V.; Matsushita, M. S.; N. E.; Vieira, O. A.; Arch. Latinoam. Nutr. 2001, 47, 4.

44. Rufino, M. D. M.; Alves, R. E.; Brito, E. S.; Perez-Jimenez, J.; Saura-Calixto, F.; Mancini Filho, J.; Food Chem. 2010, 121, 996.

45. Danner, M. A. I.; Citadin, S. A. Z.; Sasso, S. S.; Benin, G.; Rev. Bras. Fruticultura 2011, 33, 517.

46. Cavalcante, P. B.; Frutas Comestíveis da Amazônia, 7ª ed.; Museu Paraense Emílio Goeldi: Belém, Brasil, 2010.

Submitted: December 3, 2015

Published online: March 3, 2016 